\title{
Above-ground phytomass dynamics in a grassland steppe of Patagonia, Argentina
}

\author{
GUILLERMO E. DEFOSSE, M.B. BERTILLER, AND J.O. ARES
}

\section{Abstract}

Aerial phytomass and litter dynamics of a grassland steppe in Patagonia, Argentina, were studied at either monthly or bimonthly intervals for 2 years. This area is characterized by a cold and wet winter (June to September) and a warm and dry summer (December to March). The growing season extends from September to April, with moist spring and fall periods interrupted by a midsummer drought. Festuca pallescens (St. Yves) Parodi produced about $95 \%$ of the total annual phytomass. Peaks of green phytomass were recorded in spring-summer of the first growing season $\left(33.6 \pm 2.9 \mathrm{~g} \bullet \mathrm{m}^{-2}\right)$ and in early spring $\left(35.0 \pm 2.4 \mathrm{~g} \bullet \mathrm{m}^{-2}\right)$ and fall $\left(32.7 \pm 2.7 \mathrm{~g} \cdot \mathrm{m}^{-2}\right)$ of the second growing season. Less abundant forage grasses were Poa ligularis Nees ap Steudel, Bromus setifolius Presl., Hordeum comosum Presl., and Rytidosperma virescens (Desvaux) Nicora. Shrubs and forbs represented less than 2\% of the total annual phytomass of this grassland. The relationships between phytomass production of the main species and some environmental variables are discussed. These results contribute to the knowledge of above-ground phytomass dynamics and forage availability throughout seasons of this grassland in Patagonia, and are part of the data necessary for proper range management planning. This information will permit the designing of appropriate grazing schedules by balancing the number of grazing animals to the forage resources available.

Key Words: Festuca pallescens, bunchgrasses, Rytidosperma virescens, Poa ligularis

The Argentine Patagonia, which covers about 900 thousand $\mathrm{km}^{2}$, is unsuited for cultivation and is utilized for sheep production. The vegetation, mainly composed of shrubs and grasses, has been overgrazed by introduced livestock since the early 1900's (Soriano 1956a, 1983, Bertiller 1984, León and Aguiar 1985, Defossé and Robberecht 1987, Ares et al. in press). This region has been classified climatologically as an arid temperate desert (Walter and Box 1976) and has many climatic and vegetational characteristics similar to some western North American rangelands.

One of the most important grassland areas of Patagonia occurs as a narrow belt on the foothills of the Andes, from $43^{\circ} 25^{\prime} \mathrm{S}$ to the $46^{\circ} 15^{\prime} \mathrm{S}$, appearing again south of the $51^{\circ} 05^{\prime} \mathrm{S}$ and up to $53^{\circ}$, widening toward the Atlantic Ocean to the east. The climax plant community is characterized by the predominance of the tussock grass Festuca pallescens (St. Yves) Parodi (Cabrera 1976), which comprises from 50 to $90 \%$ of the vegetation cover of this region (Soriano 1948, 1956a). Other less abundant grass genera are Bromus, Hordeum, Poa, and Rytidosperma. Predominant shrub genera are Nassauvia, S necio, Relbunium, Perezia, Cerastium, and Mulinum.

The purpose of this study was to describe the dynamics of the

\footnotetext{
Authors are research scientists, Centro Nacional Patagónico, 28 de Julio 28, Puerto Madryn (9120), Argentina. Present address of Jorge Ares is ALUAR ALUMINIO ARGEN'TINO. C.C. 52 Puerto Madryn (9120), Argentina.

Research was funded by Consejo Nacional de Investigaciones Cientificas y Técnicas (CONICET), República Argentina.

Authors wish to thank C. Jones, G. Solari, and R. Barrena for assistance in field and laboratory work, and also C. Merino, who provided soil water potential data.

Acknowledgment is also given to Nicolas Ayling and family, who provided their ranch facilities and some environmental data.

Manuscript accepted 28 June 1989.
}

aerial phytomass of the principal grass species of this community. Emphasis was given to Festuca pallescens phytomass dynamics and its relationship to environmental variables.

Up to the present time, range management in Patagonia has been carried out based only on empirical observations. This study quantifies the production of this grassland.

\section{Methods}

\section{Study Site}

The study was conducted at Media Luna Ranch, $630 \mathrm{~m}$ above MSL $\left(45^{\circ} 36^{\prime} \mathrm{S}, 71^{\circ} 25^{\prime} \mathrm{W}\right)$ on the Mayo River terraces. The site is characterized as Festuca pallescens grassland steppe (Anchorena, unpublished report. Beeskow et al. 1987). Soils are uniform, coarse textured, and well drained. They accumulate organic matter in the surface and down to $30 \mathrm{~cm}$. The pH is slightly acid to neutral. Soils lack calcium carbonate, are fine gravelly on the surface and stony below (Xerorthents, Beeskow et al. 1987).

The native perennial forage grasses on the site are: Festuca pallescens, Bromus setifolius Presl., Poa ligularis Nees ap Steudel., Hordeum comosum Presl., Rytidosperma virescens (Desvaux) Nicora., and Koeleria vurilochensis Calderon. Other non-grass species consumed by sheep are Relbunium richardianum (Gill ex. Hook. et Arn.) Hicken., Polygala darwiniana Benn., Cerastium arvense Linne, and Haplopappus diplopappus Remy. Senecio sericeo-nitens Spegazzini, Nassauvia abreviata (Hook et Arn.) Dusen, Mulinum spinosum (Cav.) Pers., and Perezia lanigera Hooker et Arnott, are not consumed by sheep.

This area has a cold and wet winter (June to September), and a warm and dry summer (December to March). The growing season extends from September to April, with moist spring and fall periods interrupted by a mid-summer drought. Mean annual temperature is $4.5^{\circ} \mathrm{C}$ and July $\left(-3.7^{\circ} \mathrm{C}\right)$ and January $\left(11.7^{\circ} \mathrm{C}\right)$ are the coldest and hottest months, respectively (Fig. 1A). Average precipitation is $374 \mathrm{~mm}$ per year (Fig. 1B) with 67\% falling during winter and early spring as either rain or snow. There is no frost free period, and strong westerly winds blow continuously throughout the year.

\section{Data Collection}

A 2.5-ha exclosure was constructed at Media Luna Ranch in March 1981 (late summer in southern hemisphere) to exclude grazing by large herbivores (sheep, cattle, and horses). Aerial phyt omass and litter were collected at monthly or bimonthly intervals within the exclosure in 15 circular plots $1 \mathrm{~m}$ in diameter. The number, shape, and size of the plots were assessed in exploratory trials to produce phytomass data of the main species within $10 \%$ of error of the mean at 5\% level according to the Milner and Hughes (1970) formula. The sampling procedure followed the technique proposed by McIntyre (1951) using 3 ranked sets per plot to be harvested. Phytomass was harvested at the soil surface and litter collected. Phytomass of each forage grass species was handseparated into green (photosynthetically active tissues), dry (tissues completely dry yellow), and old dead (tissues deteriorated, gray colored). Each phytomass category was then oven-dried at $70^{\circ} \mathrm{C}$ to constant weight, and weighed. 

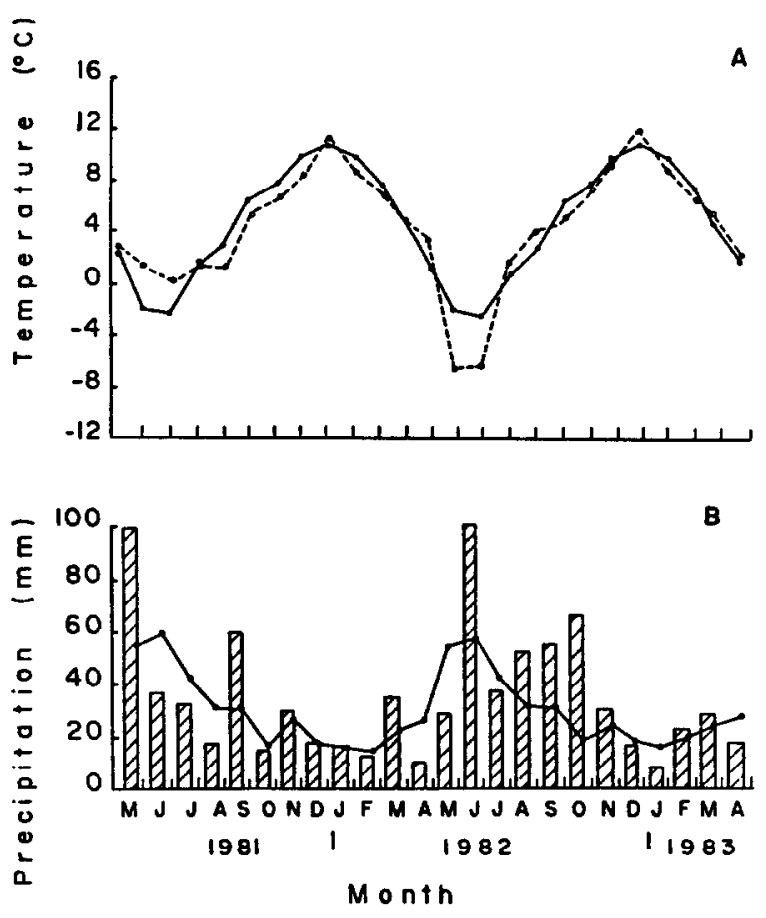

Fig. 1. (A) Mean monthly temperatures (dotted line) and 10-year monthly temperature means (solid line) for Media Luna Ranch in Patagonia. (B) Monthly precipitation values during the 2 growing sensons considered (vertical bars). Horizontal line represents 10-year mean.

Data of daily temperatures and rainfall were recorded at the site. Cylindrical soil samples of $4 \mathrm{~cm}$ in diameter were collected inside the harvested plots in 3 layers ( 0 to 20,20 to 40 , and 40 to $60-\mathrm{cm}$ soil depth), to fully represent the soil profile explored by the root system of Festuca pallescens in that area. These samples were used for estimating soil water potential of each layer with the filter paper method given by McQueen and Miller (1968). This method measures gravimetric water content of a calibrated filter paper enclosed in sealed cans containing the soil samples, and water potential is determined from a known water release curve.

\section{Results and Discussion}

\section{Vegetation Composition Dynamics}

Vegetation cover throughout the study period averaged around $55 \%$ ranging from 51 to $58 \%$. A low C.V. (15\%) of this estimate indicates a regular spatial distribution of the vegetation on the study site. This homogeneity, partially explained by the uniformity of the soils of this area (Beeskow et al. 1987), may also be attributed to the relatively low degree of deterioration compared to other areas of the same community, in which top-soil has been removed and native grasses have been replaced by undesirable shrubby species (Ares et al. in press).

Festuca pallescens was the dominant species, producing around 95\% of the aerial phytomass of this community at all sampling dates (Fig. 2). The rest of the forage grasses contributed about 3\%, with the remaining $2 \%$ composed of nongrass species, some of which are or are not consumed by sheep.

Festuca pallescens is considered to be one of the best Patagonian forage species because of its palatability and preference by sheep (Boelcke 1957, Parodi 1959). The rest of the forage grasses are important components of sheep diets in similar areas of northern Patagonia during winter time (Bonvisutto et al. 1983).

Festuca pallescens showed peaks of green phytomass in December

\begin{tabular}{l} 
E \\
D \\
0 \\
0 \\
0 \\
E \\
0 \\
5 \\
$E$ \\
0 \\
0 \\
5 \\
0 \\
0 \\
0 \\
0 \\
0 \\
0 \\
0 \\
\hline
\end{tabular}

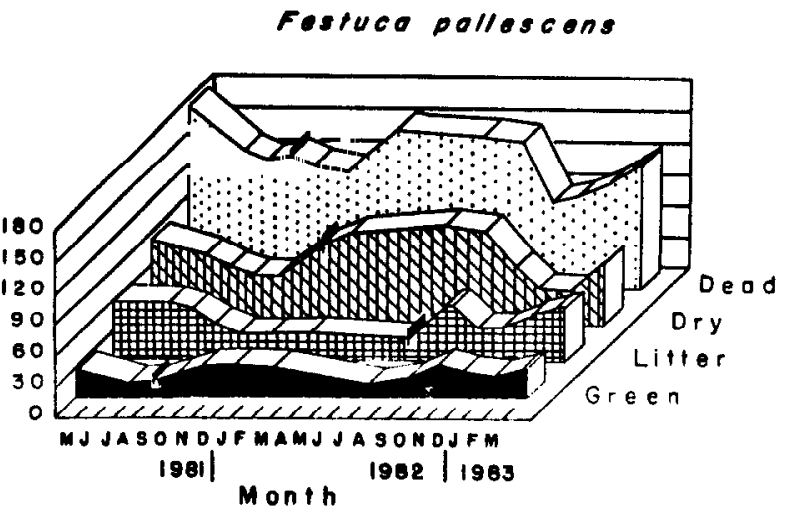

Fig. 2. Phytomass dynamics of Festuca pallescens at Media Luna Ranch in Patagonia during the 2 growing seasons considered. Vertical planes represent maximum standard error for a given component.

of the first growing season $\left(33.6 \pm 2.9 \mathrm{~g} \bullet \mathrm{m}^{-2}\right)$ and in October $(35.0$ $\left.\pm 2.4 \mathrm{~g} \cdot \mathrm{m}^{-2}\right)$ and $\operatorname{March}\left(32.7 \pm 2.7 \mathrm{~g} \cdot \mathrm{m}^{-2}\right)$ of the second growing season (Fig. 2). The lowest green phytomass values were recorded during wintertime (July) on both years, with $15.6 \pm 1.6$ and $15.2 \pm$ $2.0 \mathrm{~g} \cdot \mathrm{m}^{-2}$, respectively. Dry and dead material tended to accumulate during winter and decreased in spring-summer. The increase of dry material in late fall and winter is caused by the senescence of green tissue produced during the preceding spring and summer. Dead material is the result of the accumulation of dry material for several years, and has a very low rate of decomposition to litter. The litter disappeared rapidly in spring-summer but slowly in fall and winter. The rapid disappearance of the litter during spring and summer may be attributed to higher biological activity (soil insects and cellulolitic bacteria) during these seasons.

The dynamics of the other forage grasses are shown in Figure 3. These species had low phytomass throughout the seasons but were very constant, appearing in at least $75 \%$ of the samples at all sampling dates. Bromus setifolius and $P$. ligularis exhibited 2 peaks of green phytomass per growing season, one in spring and the other in fall. Hordeum comosum and $R$. virescens, by contrast, showed only one peak per season, in early summer. Rytidosperma virescens and Poa ligularis significantly $(\mathrm{p} \leq 0.001)$ increased in mean phytomass by the second season. This rapid increase was probably due to the protection from grazing, since these very palatable species are normally severely grazed by sheep (Boelcke 1957, Nicora 1978, Lores et al. 1988). They may have an important role for determining range condition in this area.

\section{Environmental Factors Affecting Vegetation Dynamics}

Rains during the first and second growing season averaged 345 and $451 \mathrm{~mm}$, representing $92 \%$ and $120 \%$ of the 10 -year mean, respectively (Fig. 1B). Spring precipitation, which has a 10-year mean of $99 \mathrm{~mm}$, was 89.2 and $181.3 \mathrm{~mm}$ for the 2 periods considered. Soil water potential in the first year was maximum in winter, with a rapid water depletion of the first layer in spring-early summer (Fig. 4). A lag in the water depletion of deeper layers of the soil profile is observable, with minimum soil water potentials at 40 $\mathrm{cm}$ in mid-summer and at $60 \mathrm{~cm}$ in late summer. During the second year, due to the higher spring precipitation, water potential was high throughout the profile until early summer, followed by rapid water depletion through the profile during the summer drought. This depletion, coupled with the high temperatures observed during early summer of this year, may have caused the decreased of green phytomass measured in the summer of the second year.

During the first year, temperatures were less extreme and above- 


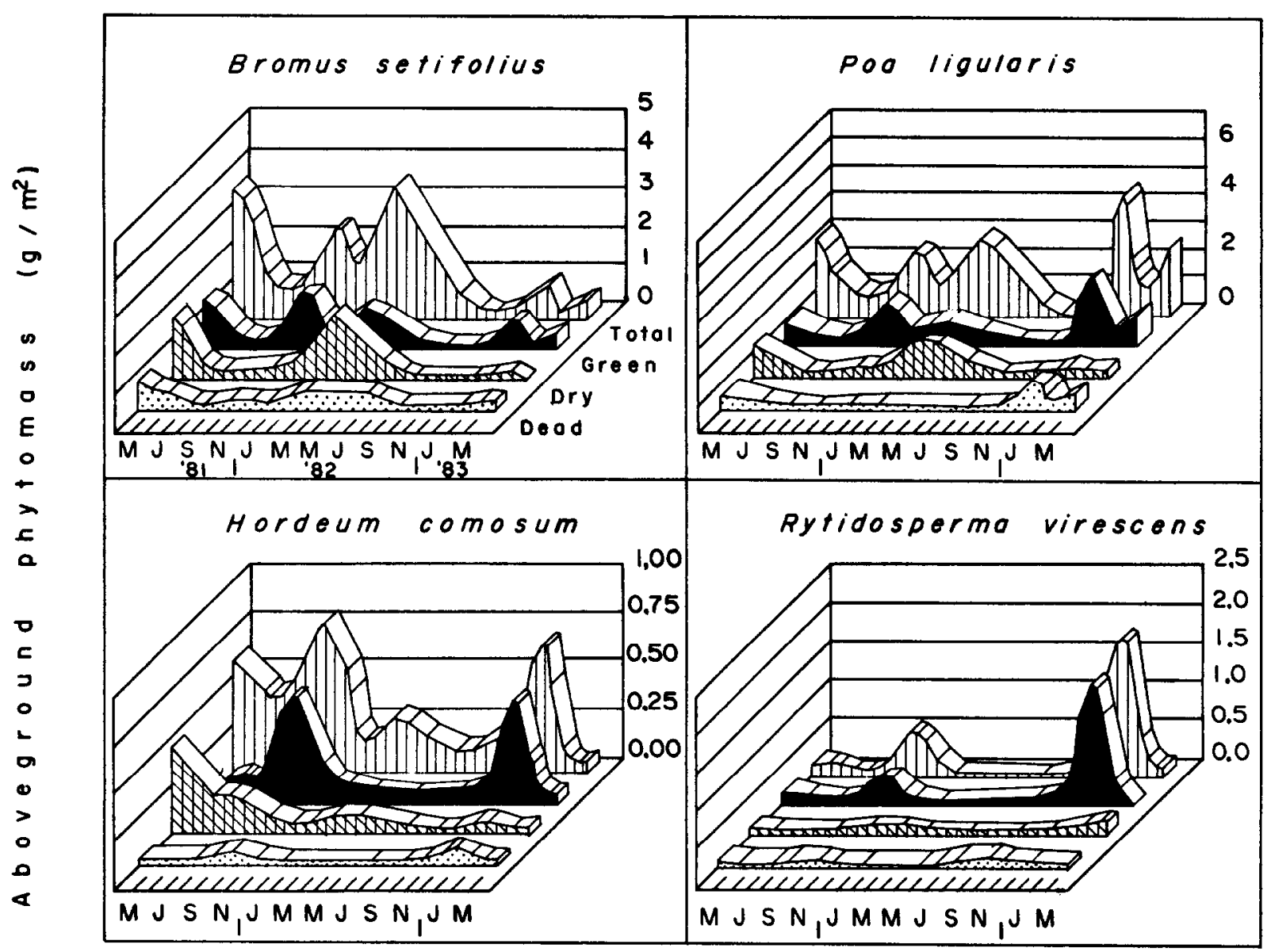

$M \circ n+h$

Fig. 3. Phytomass dynamics of forage grasses at Media Luna Ranch in Patagonia. For any compartment, maximum standard error did not exceed $30 \%$ of the mean.

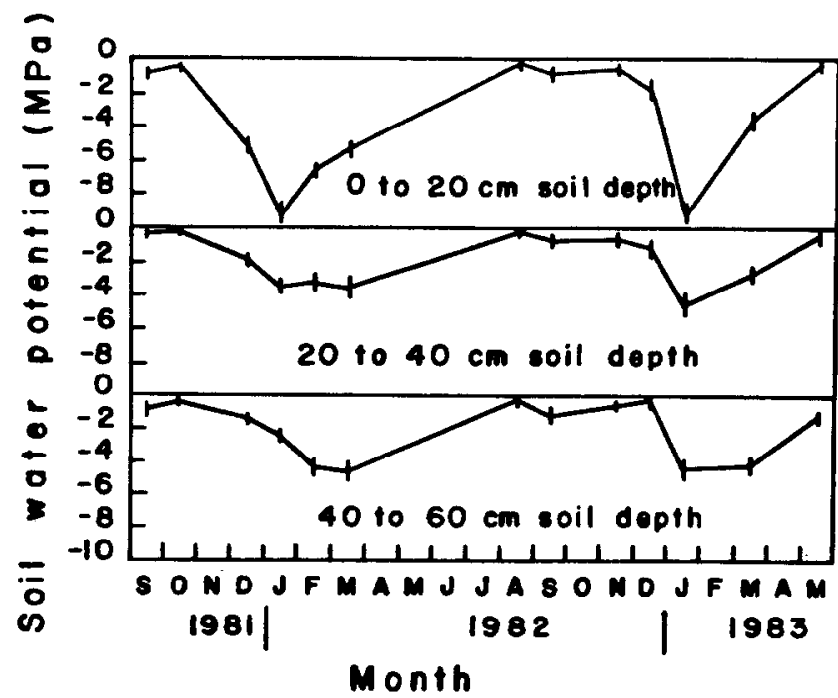

Fig. 4. Water potential for the soils of Media Luna Ranch in Patagonia. Vertical bars are the standard errors, and each value represents the average of 6 samples. normal during wintertime, but were below normal in spring, summer, and fall (Fig. 1A). During the second year, winter temperatures (June-July) were below normal, rapidly increased in early spring to exceed the long-term mean (4.2 compared to $1.8^{\circ} \mathrm{C}$, respectively).

The growth of Festuca pallescens can be related to the patterns of environmental factors described. During the first growing season, spring growth started in September, when mean temperatures increased to about $6^{\circ} \mathrm{C}$ and the soil had high water availability. As the season advanced, mean temperatures reached $11^{\circ} \mathrm{C}$, while soil water gradually diminished from soil surface to deeper layers. Peak phytomass was produced in December when mean temperatures reached $11.5^{\circ} \mathrm{C}$ and the soil still had available water. In the second year, green phytomass production in winter (abnormally cold) was similar to what it was in the preceding cycle $(15.6 \pm 1.6$ and $15.2 \pm$ $2.0 \mathrm{~g} \bullet \mathrm{m}^{-2}$, respectively). Spring growth begun earlier, probably due to more favorable temperatures and high soil water availability. The increase of phytomass continued until early summer, when the soil water potential was at a minimum. Low water availability and high temperatures may have limited green phytomass production in mid-summer. Growth begun again in fall when the soil was replenished with rainfall water and mean temperatures $\left(6.5^{\circ} \mathrm{C}\right)$ were still favorable for growth.

The water holding capacity of the soils of this area is limited because of their sandy texture (Rostagno, pers. comm.). Although spring rains during the second year were twice the 10-year mean (181 compared to $99 \mathrm{~mm}$, respectively), by mid-summer the soil 
water availability was at a minimum. Because of the low water holding capacity of these soils, most of the water was probably lost by deep percolation and was unavailable for plant growth in mid-summer.

Although mean temperatures ranging from 6 to $11^{\circ} \mathrm{C}$ seem to be the most favorable for growth of $F$. pallescens, extremely low temperatures such as those observed during the winter of the second season seem to have not affected tiller survival. Soriano (1956b) observed that most of the Patagonian bunchgrasses including $F$. pallescens lack a dormant period, maintaining active tillers during the winter. Festuca pallescens showed a growth behavior similar to Agropyron spicatum (Pursh) Scribn. and Smith and Agropyron desertorum (Fisch. ex Link) Schult., grown in North America. Nowak and Caldwell (1984) have suggested that tissues remain active, and winter activity may facilitate early spring growth. Similar winter activity has been observed in successional winter annuals (Regehr and Bazzaz 1976), hardened winter wheat (Barta and Hodges 1970), and arctic grasses grown at near $0^{\circ} \mathrm{C}$ (Tieszen 1975).

With low to moderate degrees of disturbance caused by introduced grazers, this community is widely dominated by Festuca pallescens. The other forage grasses may have a role for sheep diets during the summer, but their low phytomass values compared to $F$. pallescens make them relatively inconsequential for forage production in this area.

Up to the present time, range management in Patagonia has been based only on empirical observations. An understanding of the dynamics of the phytomass and forage availability of this grassland throughout the seasons will facilitate appropriate range management planning by balancing the number of grazing animals to the forage resources available.

\section{Literature Cited}

Ares, J.O., A.M. Beeskow, M.B. Bertiller, C.M. Rostagno, M.P. Irisarri, J. de Anchorena, G.E. Defosse, and C.A. Merino. (In press). Structural and dynamic characteristic of overgrazed grasslands of Northern Patagonia. In: A Breymeyer (ed.) Managed Grasslands: Regional Studies. Elsevier, Amsterdam.

Barta, A.L., and H.F. Hodges. 1970. Characterization of photosynthesis in cold hardening winter wheat. Crop Sci. 10:535-538.

Beeskow, A.M., H. Del Valle, and C.M. Rostagno. 1987. Los sistemas fisiográficos de la region árida y semiárida de la Provincia del Chubut. Secretaria de Ciencia y Técnica, Delegación Regional Patagónica. Bariloche, Argentina.
Bertiller, M.B. 1984. Specific primary productivity dynamics in arid ecosystems: a case study in Patagonia, Argentina. Acta Oecologica/Oecologia Generalis 5:365-381.

Boelcke, 0. 1957. Comunidades herbáceas del norte de la Patagonia y su relación con la ganaderia. Revista de Investigaciones Agricolas 11:5-98.

Bonvisutto, G., E. Moricz de Tecso, O. Astibia, and J. de Anchorena. 1983. Resultados preliminares sobre hábitos dietarios de ovinos en un pastizal semidesértico de Patagonia. Revista del Instituto de Investigaciones Agricolas (IDIA) suplemento 36:243-253.

Cabrera, A.L. 1976. Regiones Fitogeográficas Argentinas. Enciclopedia Argentina de Agricultura y Jardineria I. ACME, Buenos Aires.

Defossé, G.E., and R. Robberecht. 1987. Patagonia: range management at the end of the world. Rangelands 9:106-109.

León, R.J.C., and M.R. Aguiar. 1985. El deterioro por uso pasturil en estepas herbáceas Patagónicas. Phytocoenologia 13:181-196.

Lores, R.D., C.A. Ferreira, and G. Bonvisutto. 1988. Evalucación del uso de tres potreros con distinta carga ovina en la estepa arbustiva patagónica. Ecologia 8:11-28.

McIntyre, G.C. 1951. A method for unbiased selective sampling, using ranked sets. Aust. J. Agr. 3:385-390.

McQueen, L.S., and R.F. Miller. 1968. Calibration and evaluation of a wide range gravimetric method for measuring water stress. Soil Sci. 3:225-231.

Milner, C., and R.E. Hughes. 1970. Methods for the measurement of the primary production. IBP Handbook No 6. Blackwell Sci. Pub. Co., Oxford.

Nicora, E. 1978. Flora Patagónica. III. Gramineae. Colección Cientifica del Instituto Nacional de Tecnologia Agropecuaria (INTA). Buenos Aires.

Nowak, R.S., and M.M. Caldwell. 1984. Photosynthesis activity and survival of foliage in winter for two bunchgrass species in a cold-winter steppe environment. Photosynthetica 18:192-200.

Parodi, L.R. 1959. Descripción de las plantas cultivadas. Enciclopedia Argentina de Agricultura y Jardineria I. ACME, Buenos Aires.

Regehr, D.L., and F.A. Bazzaz. 1976. Low temperature photosynthesis in successional winter annuals. Ecology 57:1297-1303.

Soriano, A. 1948. La vegetación del Chubut. Revista Argentina de Agronomia 17:30-66.

Soriano, A. 1956a. Los distritos floristicos de la provincia Patagónica. Revista de Investigaciones Agricolas 10:323-342.

Soriano, A. 1956b. Aspectos ecológicos y pasturiles de la vegetación Patagónica relacionados con su estado y capacidad de recuperación. Revista de Investigaciones Agricolas 10:349-372.

Soriano, A. 1983. Deserts and Semideserts of Patagonia. p. 424-460 In. N.E. West, ed. Temperate deserts and semideserts. Elsevier, Amsterman.

Tieszen, L.L. 1975. $\mathrm{CO}_{2}$ exchange in the Alaskan Arctic tundra: Seasonal changes in the rate of photosynthesis of four species. Photosynthetica 9:376-390.

Walter, H., and E.O. Box 1976. Global classification of natural terrestrial ecosystems. Vegetatio 32:75-81. 